\title{
Application of Linear Programming Model for Industrial Supply Chain Network Design: A Case Study
}

\author{
Temesgen Garoma $^{1^{*}}$ and Daniel Kitaw ${ }^{2}$ \\ ${ }^{1}$ Department of Mechanical Engineering, College of Engineering and Technology, Wollega University, \\ Post Box No: 395, Ethiopia \\ ${ }^{2}$ School of Industrial and Mechanical Engineering, Addis Ababa Institute of Technology, \\ Addis Ababa University, Addis Ababa, Ethiopia
}

\begin{tabular}{|c|c|}
\hline & \multirow{2}{*}{\begin{tabular}{l}
\multicolumn{2}{c}{ Article Information } \\
Article History: \\
Received : $03-04-2013$ \\
Revised $: 26-06-2013$ \\
Accepted $: 28-06-2013$ \\
\end{tabular}} \\
\hline \multirow{3}{*}{$\begin{array}{l}\text { A Linear Programming Model (LPM) capturing many practical aspects of network } \\
\text { design problems and the optimization techniques, like transportation model, to be } \\
\text { used were introduced in this study. The objective is to design the supply chain (SC) } \\
\text { network so as to minimize annual system-wide costs and improve service level } \\
\text { requirements, thereafter increase market share. This is because at current practices } \\
\text { most companies do not have a means to sense real situations at their SC. The } \\
\text { design approaches employed here followed three major methods namely data } \\
\text { collection and aggregation; modeling and data validation; and use of solution } \\
\text { techniques to produce a good optimized result. Finally, a general LPM that } \\
\text { simultaneously locates multi plant and warehouses is applied to the case company } \\
\text { that results in optimization of current network, design of new SC network, and large } \\
\text { cost savings. }\end{array}$} & \\
\hline & $\begin{array}{l}\text { Keywords: } \\
\text { Linear Programming Model } \\
\text { Network Design } \\
\text { Optimization } \\
\text { Case Study } \\
\text { Supply Chain }\end{array}$ \\
\hline & $\begin{array}{l}\text { *Corresponding Author: } \\
\text { Temesgen Garoma } \\
\text { E-mail: } \\
\text { temgarom@yahoo.com }\end{array}$ \\
\hline
\end{tabular}

\section{INTRODUCTION}

In recent years, numerous approaches have been proposed to improve manufacturing plant operations performance. Among many others, supply chain management has received considerable attentions. Despite its benefits, structuring supply chain (SC) network is a complex decision making process. At strategic level companies have to decide where to locate new facilities, how to allocate resources to the various facilities, and how to manage the transportation of products through the chain in order to satisfy customer demands.

As Christopher (1992), Suhong (2006), and Nicholas (2005) have reported effective supply chain management (SCM) has becomes a potentially valuable way of securing competitive advantage and improving organizational performance since competition is no longer between organizations, but among supply chains. The phrase "Supply Chain Management" came in to use in the early 1990s. The Global Supply Chain Forum defined SCM as the integration of key business An Official International Journal of Wollega University, Ethiopia. processes from the end user through original suppliers that provide products, services, and information that add value for customer Peter and Groznik (2006).

The benefits of an effective SC can be: cycle time reduction, inventory cost reduction, optimized transportation, increased order fill rate, early prediction of disturbance to downstream, increase customer service, and increase returns on assets Change (2009) and Gunasekaran (2004). To achieve these benefits, the decisions that are to be taken should be strategic, tactical, and operational.

The principles of SCM that can ensure the above benefits are (1) customer segmentation, (2) customizing SC networks, (3) demands planning, (4) sourcing suppliers strategically, (5) integration of technology, and (6) performance measure Daniel (2005) and David (1997). The supply network must be optimized and react to supply uncertainties and demand variability to serve customers demand Steven (2006). 
Temesgen Garoma et al.,

In general, different authors agree that SCM involves in integrating three key flows across the boundaries of the supply chain: product/material, information, and financial flow Change (2009); Chopra (2006) and Handfield (2006). Figure 1 below shows a simplified supply chain management system.

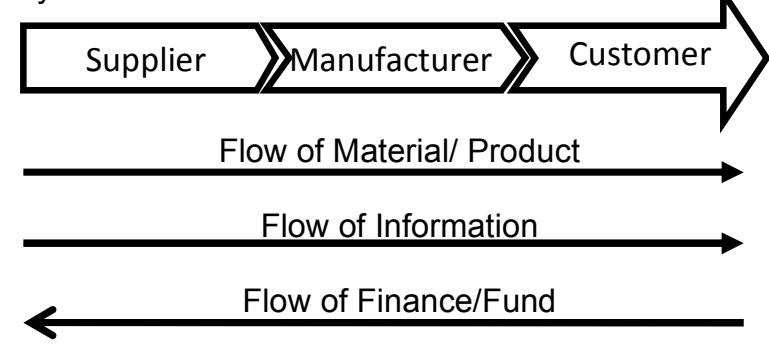

Figure 1: Simplified supply chain diagram.

Successful integration of the three flows has produced improved efficiency and effectiveness. Hence, the initial step in implementing and practicing SCM system is supply chain network design. Therefore, the study is mainly focusing on SC network design.

Numerous modeling approaches in SCM have been proposed so far, these includes linear programming, mixed integer programming, stochastic programming, heuristic methods, and simulation based methods of Gunasekaran (2004); Daniel (2005); Bernard (1996); Stamey (2007); Vidal (2001); Beamon (1998); and Thomas (2005). Among all, in this study especial focus is given to SC network design with Linear programming models or techniques. This is because it considers the structure of the network and also incorporates other optimization models to reach at final decisions.

\section{MATERIALS AND METHODS}

Network configuration may involve issues relating to plant, warehouse, transportation, and retailer location. These are strategic decisions since they have a long-lasting effect on the firm. To come up with a better network design, appropriate number of warehouses, location of each warehouse, and the size and capacity of each warehouse has to be identified and determined.

The objective is to design the SC network so as to minimize annual system-wide costs and improve service level requirements, thereafter increase market share. Increasing the number of warehouses typically yields: improvement in service level, increase in inventory costs, increase in overhead and set-up costs, reduction in outbound transportation costs, and increase in inbound transportation costs. In this setting, the tradeoffs are
Sci. Technol. Arts Res. J., April-June 2013, 2(2): 105-114

clear. In essence, the firm must balance the costs of opening new warehouses with the advantages of being close to the customer. Thus, warehouse location decisions are crucial determinants for the efficiency of the product distribution. The design approaches therefore, require the following three major activities to produce a good optimized result Chopra (2006).

1. Data collection and aggregation regarding transportation rates, mileage estimation, warehouse costs, \& service level requirements;

2. Modeling and data validation; and

3. Use of solution techniques.

A general Linear Programming Model (LPM) of the distribution network design is as presented in equation 1 . In the equation we get three different models namely: pure linear programming, integer programming and transportation model. The total cost function is the minimum value of sum of fixed plants and warehouses costs (integer programming and linear programming), and transportation cost in supply of raw material and distribution of finished goods (transportation model). This model can simultaneously locate multi plant and warehouses for a company. The constraints to this objective function are given in equation 2 to equation 9 .

\section{Objective Function}

Total cost $=$ Min

$$
\left\{\sum_{i=1}^{n} F_{i} Y_{i}+\sum_{e=1}^{t} F_{e} Y_{e}+\sum_{h=1}^{l} \sum_{i=1}^{n} C_{h i} X_{h i}+\sum_{i=1}^{n} \sum_{e=1}^{t} C_{i e} X_{i e}+\sum_{e=1}^{t} \sum_{j=1}^{m} C_{e j} X_{e j}\right\}
$$

\section{Subject to Constraints}

Total amount shipped from supplier cannot exceed supplier's capacity;

$\sum_{i=1}^{n} X_{h i} \leq S_{h}$ for $h=1,2,3 \ldots$

Amount shipped out of factory cannot exceed the quantity of raw material received;

$$
\sum_{h=1}^{l} X_{h i}-\sum_{e=1}^{t} X_{i e} \geq 0 \text { for } \mathrm{i}=1,2,3 . . \mathrm{n} \ldots \text { (3) }
$$

Units produced in factory cannot exceed factory capacity;

$$
\sum_{e=1}^{t} X_{i e} \leq \mathrm{K}_{\mathrm{i}} \mathrm{Y}_{\mathrm{i}} \text { for } \mathrm{i}=1,2,3 \ldots \mathrm{n}
$$

Amount shipped out of warehouse cannot exceed quantity received from factories; 
Temesgen Garoma et al.,

$\sum_{e=1}^{t} X_{i e}-\sum_{j=1}^{m} X_{e j} \geq 0$ for $\mathrm{e}=1,2,3 . . t . . . .$.

Amount shipped through warehouses cannot exceed its capacity;

$\sum_{j=1}^{m} X_{e j}$

$\leq$ WeYe for $e=1,2,3 \ldots t$

Amount shipped to customer must equal the customer demand; and

$$
\sum_{e=1}^{t} X_{e j} \quad=\mathrm{D}_{\mathrm{j}} \text { for } \mathrm{j}=1,2,3 \ldots \mathrm{m}
$$

Each factory or a warehouse is either open or closed.

$\mathrm{Y}_{\mathrm{i},} \mathrm{Y}_{\mathrm{e},} \in\{0,1\}$

$X_{i e}, X_{e j} \geq 0$

Where,

$\mathrm{m}$ = number of markets or demand points

$\mathrm{n} \quad=$ number of potential factory locations

I = number of suppliers

$\mathrm{t} \quad=$ number of potential warehouse locations

$D_{j}=$ annual Demand from customer $\mathrm{j}$

$\mathrm{K}_{\mathrm{i}}=$ potential Capacity of factory at site $\mathrm{i}$

$S_{h}=$ supply capacity at supplier $h$

$\mathrm{W}_{\mathrm{e}}=$ potential warehouse capacity at site e

$F_{i}=$ fixed Cost of locating a Plant at site $i$

$F_{e}=$ fixed cost of locating a warehouse at site e

$\mathrm{C}_{\mathrm{hi}}=$ cost of shipping one unit from supply source $\mathrm{h}$ to factory $\mathrm{i}$

$\mathrm{C}_{\mathrm{ie}}=$ cost of shipping one unit from factory $\mathrm{i}$ to warehouse e

$\mathrm{C}_{\mathrm{ej}}=$ cost of shipping one unit from warehouse e to customer j

$Y_{i}=1$ if plant is located at site $i, 0$ otherwise

$Y_{e}=1$ if warehouse is located at site e, 0 otherwise

$\mathrm{x}_{\mathrm{ej}} \quad=$ quantity transported from warehouse $\mathrm{e}$ to market j

$\mathrm{X}_{\mathrm{ie}}=$ quantity transported from plant $\mathrm{i}$ to warehouse e

$\mathrm{X}_{\mathrm{hi}}=$ quantity shipped from supplier $\mathrm{h}$ to factory at site i.

Once the model has been developed based on network configurations, the next step is to optimize the configuration of the logistics network. In practice, mathematical optimization techniques, which include exact algorithms that are guaranteed to find optimal solutions is used. A case study of East Africa Bottling Share Company has been undertaken to validate the model development of the supply chain network design; to find possible ways of reconfiguring the distribution centers; and find areas of optimization. In the study extensive data collection and analysis has been carried out. Also promising results have been achieved.
Sci. Technol. Arts Res. J., April-June 2013, 2(2): 105-114

\section{Data Collection and Analysis}

A case study of East Africa Bottling Share Company has been undertaken to validate the model development of the supply chain network design; to find possible ways of reconfiguring the distribution centers; and find areas of optimization. In the study, extensive data collection and analysis has been carried out. Also promising results have been achieved.

In the current business operations of the company, some segments of the markets for the company's product experience shortage (Figure 2). The shortage may either be owing to shortage of supply from the company or lack of supply to specific market segment while excess supply is experienced in others. This means the company is losing its sale because the customer may cancel the order or shift to some other brand. But the company does not have well established means to sense market where shortage is experienced and also mechanisms how to supply the market accordingly. Hence, new supply chain network design will be developed and evaluated with the Linear Programming Model (LPM) for the company.

\section{Existing Supply Chain Network Diagram of the Company}

To clearly portray how the Linear Programming Model of SC network design works, it is important to thoroughly scrutinize the existing SC structure of the company. The company has few geographic regions which it directly supplies, seven regional towns and Addis Ababa, whereas the rest regions are supplied by agents whose numbers are variable. A simplified schematic diagram of the SC for the company's existing operation is given in Figure 2.

\section{Raw material Type and Price Analysis}

The raw materials that are utilized for the production of the company's product mix include concentrate, sugar, bottle, crown, Carbone dioxide $\left(\mathrm{CO}_{2}\right)$ and caustic soda. Table 1 depicts the sources of raw materials.

\section{Production Capacity of the Company}

The two plants of the company are operating at about 90 percent of actual production capacity. This is far greater than the actual demands shown in Table 3 by 388,000 cases. Therefore, for all practical purposes production capacity of 90 percent will be used. Table 2 shows the capacities of the two plants. 


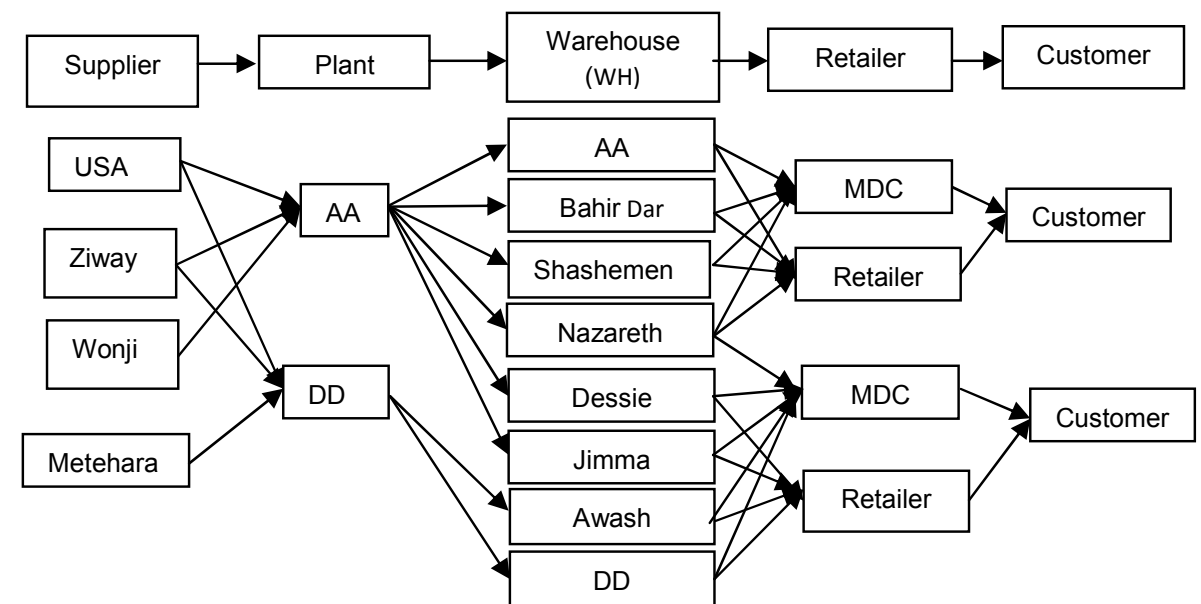

USA $=$ United States of America, $A A=$ Addis Ababa, DD=Dire Dawa, MDC= Manual Distribution Centers

Figure 2: Existing supply chain network of the case company.

Table1: Raw material type, sources and their respective prices.

\begin{tabular}{cll}
\hline No & Raw Material & Source \\
\hline 1 & Concentrate & USA \\
2 & Sugar & Wonji/Metehara \\
3 & Bottle & AA \\
4 & Crown & AA \\
5 & $\mathrm{CO}_{2}$ & In house production \\
6 & Caustic Soda & Ziway \\
\hline
\end{tabular}

Warehouses and their Supply Regions

There are five warehouses that receive deliveries directly from the manufacturing plant at Addis Ababa. Warehouses and their supply regions are,

- Addis Ababa market is supplied by 265 Manual Distribution Centers (MDCs).

- Awash is mainly supplied by the plant at Dire Dawa

- Nazareth warehouse covers Nazareth, Mojjo, Ziway, Arsi, and Wolenchiti areas.

- Shashemene warehouse covers demand regions of Awassa, Bale, and Arsi-Negelle.

- Dessie warehouse supplies areas within radius of $20 \mathrm{Km}$ excluding Kombolcha.

- Bahir Dar warehouse covers regions to Chagni and Addis-Zemen.

- Jimma warehouse supplies Jimma-Agaro and Jimma-Sekoro.

The remaining geographic regions are supplied by agents who have franchise from the Company. Other basic data are presented in the next section.

\section{Basic Data Presentation and Related costs}

Described below are some of the issues related to data collection and the calculation of costs required for the optimization models.
Table 2: Actual production capacity of the company per year.

\begin{tabular}{ccccc}
\hline \multicolumn{5}{c}{ Capacity in Cases per year } \\
\hline Plants & Line 1 & Line 2 & Line 3 & Total \\
\hline Addis & 660,000 & 816,000 & $1,440,000$ & $2,916,000$ \\
Ababa & & - & - & 468,000 \\
DD Plant & 468,000 & & & $3,384,000$ \\
\hline
\end{tabular}

\section{(i) Annual Demand at Warehouses}

In Addis Ababa, each retailer is supplied by manual distribution centers (MDCs) nearby. It can be assumed that demand is concentrated at the point of MDC location. The MDCs can further be aggregated based on the total distance to serve a specific market segment. This is determined by the customer service level set by the company, which is 12 hours a day.

In regions where there are warehouses, demand is taken to be fixed at the warehouse location. In fact there are places which can have supply from multiple warehouses. As there is no warehouse in Addis Ababa, the company directly ships and sells its products to agents at MDCs. In such cases, multiple of MDCs are grouped based on their geographic proximity to represent demand at a specific location. All MDCs at Addis Ababa are summed together to represent a single warehouse. As a result there are demand locations at seven towns. The amount of cases shipped to these destinations annually (average) is given in Table 3. 
Table 3: Annual demands at depots (warehouses).

\begin{tabular}{ccccccccc}
\hline Warehouse & AA & Bahir Dar & Dessie & Jimma & Nazareth & Shashemene & Awash & DD \\
Demand & 1284800 & 183040 & 183040 & 183040 & 274560 & 274560 & 91520 & 183040 \\
\hline \multicolumn{1}{c}{ Source: Company's report }
\end{tabular}

\section{(ii) Transportation Rates}

The cost of transporting products from a specific source to a specific destination is a function of the distance between these two points. The cost per case of soft drink per $\mathrm{km}$ can be calculated in two ways. Firstly, assuming that third party vehicles can be rented and secondly, using own transport system. Considering the relevant carrier and operational costs, the average transportation cost per case per Kilometer is found to be 0.06 Birr in a round trip. The summary for all cases are presented in the following three consecutive tables $(4,5 \& 6)$.

Table 4: Warehouses and their distances from the plants in Kilometers.

\begin{tabular}{lllllllll}
\hline \multirow{2}{*}{ Fo } & \multicolumn{8}{c}{ Warehouse Locations } \\
\cline { 2 - 8 } & AA & Bahir Dar & Dessie & Jimma & Nazareth & Shashemene & Awash & DD \\
\hline AA plant & 0 & 560 & 400 & 335 & 100 & 250 & 240 & 515 \\
DD plant & 515 & 1075 & 915 & 830 & 415 & 695 & 275 & 0 \\
\hline \multicolumn{7}{c}{ Note: The warehouses at AA \& DD are integrated with the plant }
\end{tabular}

Table 5: Type of trucks and their capacity

\begin{tabular}{cllllll}
\hline \multirow{2}{*}{ No. } & \multirow{2}{*}{ Type } & \multicolumn{3}{c}{ Number of trucks } & \multicolumn{3}{c}{ Capacity in cases } \\
\cline { 2 - 6 } & AA & DD & Total & AA & DD \\
\hline 1. & 4 Pallet truck & 15 & 3 & 18 & 4500 & 900 \\
2. & 6 Pallet truck & 2 & 9 & 11 & 900 & 4050 \\
3. & 8 Pallet truck & 2 & 2 & 4 & 1200 & 1200 \\
4. & 10 Pallet truck & 1 & 0 & 1 & 750 & 0 \\
5. & Hauler Trailer(22 pallet) & 15 & 9 & 24 & 33000 & 19800 \\
$\quad$ Total & & & & 40350 & 25950
\end{tabular}

Note: A 4 pallet truck has a capacity of transporting 300 cases. A single pallet means $300 / 4$ which is equal to 75 cases. Therefore, capacities of other trucks can be calculated by multiplying their pallet capacity by 75 .

The company uses vender managed inventory and agents must fulfill minimum criteria to qualify for it. Agents owned trucks and their capacity are given in Table 6.

Table 6: Types of third party trucks and their capacity.

\begin{tabular}{|c|c|c|c|c|c|c|c|c|c|c|c|}
\hline \multirow{2}{*}{ No. } & \multirow{2}{*}{ Type } & \multicolumn{10}{|c|}{ Location } \\
\hline & & AA & WH & Nazareth & Shash & Mekelle & Jimma & DD & De & BD & Total \\
\hline 1 & 4 Pallet & 16 & - & - & - & - & - & 1 & 1 & 1 & 18 \\
\hline 2 & 6 Pallet & - & - & - & - & 2 & - & - & - & - & 11 \\
\hline 3 & 8 Pallet & 13 & - & 5 & 4 & 7 & 2 & 2 & - & - & 4 \\
\hline 4 & Hauler Trailer & - & 16 & - & - & - & - & 9 & & - & 24 \\
\hline
\end{tabular}

(iii) Potential Warehouse Locations:

This factor is considered to use the excess production of 388,000 cases. Hence, potential warehouse locations are identified based on the factors like potential markets, weather condition, and population. Based on these considerations and company's expert discussion; Mekelle and Gonder towns were identified as warehouse locations in addition to the already located ones. The major reasons to be established in these two towns are:

- Demand is high in the two towns;

- MDCs can easily be established;

- Agents can be cultivated in nearby towns; and

- Competitor is present in Gonder town (PEPSI COLA) 
Temesgen Garoma et al.,

(iv) Warehouse Capacities:

The capacity of warehouses can be calculated by taking in to consideration the total physical size of the demand units. Also, factors on accounts of storing, retrieving, and other recording place allowances are considered. Generally speaking the capacity of warehouse is referred to as the average amount of demand the warehouse serves. In this particular case, the warehouse capacity in each location is found to be the peak weekly demands as shown in table 3 on annual base.

\section{(v) Warehouse Costs:}

From related warehouse costs, only warehouse fixed cost is needed to be found for the very reason
Sci. Technol. Arts Res. J., April-June 2013, 2(2): 105-114

that (1) it is this cost that widely differs from place to place, and (2) it is incurred regardless of the amount of material stored. Fixed warehouse costs at both Addis Ababa and Dire Dawa are integrated with the main plants. The fixed cost of warehouse for different locations is given in Table 7.

\section{(vi) Service Level Requirements:}

Though not exclusively mentioned, the company aspires to meet demand within $12 \mathrm{hrs}$. Assume that order processing and loading/unloading as well as waiting time will take a total of $6 \mathrm{hrs}$. The remaining $6 \mathrm{hrs}$ can be taken to be service level the company wants to maintain, that is about $180 \mathrm{~km}$ assuming a loaded truck travels at $30 \mathrm{~km} / \mathrm{hr}$.

Table 7: Annual warehouse fixed costs.

\begin{tabular}{ccccccc}
\hline Warehouse & Bahir Dar & Dessie & Jimma & Nazareth & Shashemene & Awash \\
\hline Fixed cost & 120000 & 100000 & 120000 & 170000 & 120000 & 100000 \\
\hline \multicolumn{5}{c}{ Source: Company's report }
\end{tabular}

\section{RESULT AND DISCUSSION}

Model formulation and data validation are typically done by reconstructing the existing network configuration using the collected data, and comparing the output of the model to existing data. Here, to validate the model, existing distribution costs to warehouses are calculated using analytical method and is compared against the optimization model done using solver. The cost of transport $/ \mathrm{km} /$ case is $0.06 \mathrm{Br}$, and the distances between the plants and warehouses are given in table 4 . Accordingly, the transportation costs/case is as depicted in table 8.

Table 8: Average transportation cost in Birr/case between plants and WH locations.

\begin{tabular}{lcccccccc}
\hline To & From & BD & Dessie & Jimma & Nazareth & Shashemene & Awash & DD \\
\hline AA plant & 0 & 33.6 & 24 & 18.9 & 6 & 15 & 14.4 & 30.9 \\
DD plant & 30.9 & 64.5 & 54.9 & 49.8 & 24.9 & 41.7 & 16.5 & 0 \\
\hline \multicolumn{7}{c}{ Source: Company's report }
\end{tabular}

Note: The warehouses at AA \& DD are integrated with the plant.

Based on the available data the total transportation cost for existing network can be calculated first analytically and then compared with the optimization solution techniques. Finally, optimization with the renewed setting will be made. (a) Analytical Approach

Table 9 shows the results of the transportation costs. Analytically, the total annual transportation cost from plants to warehouses using equation 2.1 results $21,278,400$ Birr. The actual transportation cost obtained from plants is almost equal with this value.

Table 9: Annual Costs based on transportation cost in Birr between plants and warehouses.

\begin{tabular}{cccccccccc}
\hline From & \multicolumn{8}{c}{ Warehouses } \\
\cline { 2 - 9 } To & AA & BD & Dessie & Jimma & Nazareth & Shashemene & Awash & DD \\
\hline AA Plant & 0 & 33.6 & 24 & 18.9 & 6 & 15 & 14.4 & 30.9 \\
DD Plant & 30.9 & 64.5 & 54.9 & 49.8 & 24.9 & 41.7 & 16.5 & 0 \\
Demand & 1284800 & 183040 & 183040 & 183040 & 274560 & 274560 & 91520 & 183040 \\
Cost & 0 & 6150144 & 4392960 & 3459456 & 1647360 & 4118400 & 1510080 & 0 \\
\hline
\end{tabular}


Temesgen Garoma et al.,

\section{(b) Using Solution Techniques to Optimize} Distribution Costs

A general form of the linear programming model for the distribution network is given in section 2 of equation 1 and the related constraints are given in equations 2 to 9 . In equation 1 Constraints $2 \& 3$ will have no room to entertain for this particular case company. This is because there is only one source of each categories of raw material consumed. Hence, the optimization formula can therefore, be modified to suit the company, i.e.

Total cost $=$ Min

$$
\left\{\sum_{i=1}^{n} F_{i} Y_{i}+\sum_{e=1}^{t} F_{e} Y_{e}+\sum_{i=1}^{n} \sum_{e=1}^{t} C_{i e} X_{i e}+\sum_{e=1}^{t} \sum_{J=1}^{m} C_{e j} X_{e j}\right\} \ldots \ldots(
$$

To see the benefit of supply chain network design for the company, two sets of optimization are considered:

1. Optimization based on existing set of operation of the company: in this case, the existing plant and warehouse location are fixed.
Sci. Technol. Arts Res. J., April-June 2013, 2(2): 105-114

2. Optimization with renewed setting: in this option, all warehouse locations are set to change and optimization techniques are used to arrive at a minimum cost scenario.

\section{Optimization Based on Existing Set of Operation}

Based on the existing network structures the plant at Addis Ababa supplies all the WH locations except Dire Dawa, which is supplied by the Dire Dawa plant. In the optimization approach, a built-in MS-Excel tool called solver is utilized. In this scenario, the total annual cost is found to be $\mathrm{Br}$. 21, 086,208 . Thus, it resulted in 192,192 Birr annual saving from the actual cost investigated with the analytical method which is $21,278,400$ Birr. All the demand is met and all warehouses supply demands within their proximity. The excess transportation capacities to transport 149, 840 cases from Addis Ababa and 248,960 cases from Dire Dawa are used to serve third party distributors or agents who directly take shipments from plants. The detailed analyze is shown in Table 10.

Table 10: Optimized Minimum Cost for the Existing Network.

\begin{tabular}{|c|c|c|c|c|c|c|c|c|c|}
\hline & \multicolumn{9}{|c|}{ Average Transportation cost per case (crate) between Potential WH locations } \\
\hline & $\begin{array}{l}\text { Addis } \\
\text { Ababa }\end{array}$ & $\begin{array}{l}\text { Bahir } \\
\text { Dar }\end{array}$ & Dessie & Jimma & Nazret & Shashemene & Awash & DD & Capacity \\
\hline AA plant & 0 & 33.6 & 24 & 18.9 & 6 & 15 & 14.4 & 30.9 & 2624400 \\
\hline DD plant & 30.9 & 64.5 & 54.9 & 49.8 & 24.9 & 41.7 & 16.5 & 0 & 432000 \\
\hline Demand & 1284800 & 183040 & 183040 & 183040 & 274560 & 274560 & 91520 & 183040 & \\
\hline \multicolumn{10}{|c|}{ Amount to be transported from plant WH } \\
\hline & $\begin{array}{l}\text { Addis } \\
\text { Ababa }\end{array}$ & $\begin{array}{l}\text { Bahir } \\
\text { Dar }\end{array}$ & Dessie & Jimma & Nazret & Shashemene & Awash & DD & Capacity \\
\hline AA plant & 1284800 & 183040 & 183040 & 183040 & 274560 & 274560 & 91520 & 0 & 2624400 \\
\hline DD plant & 0 & 0 & 0 & 0 & 0 & 0 & 0 & 183040 & 432000 \\
\hline Demand & 1284800 & 183040 & 183040 & 183040 & 274560 & 274560 & 91520 & 183040 & \\
\hline $\begin{array}{l}\text { Supply } \\
\text { plant }\end{array}$ & $\begin{array}{l}\text { Excess } \\
\text { Capacity }\end{array}$ & & & & & & & & \\
\hline AA & 149840 & & & & & & & & \\
\hline DD & 248960 & & & & & & & & \\
\hline $\begin{array}{l}\text { Unmet } \\
\text { Demand }\end{array}$ & 0 & 0 & 0 & 0 & 0 & 0 & 0 & 0 & \\
\hline & & & & & & & Total C & ost (TC)= & 1086208 \\
\hline
\end{tabular}

\section{Optimization with Renewed Setting}

The basic problem with agents is that, they are not likely to travel longer distances to collect shipments. For instance, it is difficult to find distributors and MDCs in towns located far from plants. The total cost they incur coupled with their capacity to satisfy market largely hampers their performance. Besides, the opportunity the company loses is taken up by competitors right away. Therefore, it is better for the company to outreach as much markets as possible. Accordingly, warehouses at Mekelle and Gondar towns are identified as potential sites in addition to the already existing ones. Other places in the country have relatively level topography and nearby to AA and DD plant, hence, agents can easily be found.

After potential places in the country have proposed, the optimal solution taking into consideration all potential market locations is formulated in the MS-Excel Solver. The problem formulation and results are as presented in Table 11. 
Table 11: Minimum cost scenario for the renewed network

\begin{tabular}{|c|c|c|c|c|c|c|c|c|c|c|c|}
\hline & \multicolumn{11}{|c|}{ Distance Matrix between the Plants and potential warehouse locations } \\
\hline & AA & Bahir Dar & Dessie & Jimma & Nazret & Shashemene & Awash & DD & Gonder & Mekelle & Capacity \\
\hline AA plant & 0 & 560 & 400 & 335 & 100 & 250 & 240 & 515 & 738 & 780 & 2624400 \\
\hline DD plant & 515 & 1075 & 915 & 830 & 415 & 695 & 275 & 0 & 1253 & 1295 & 432000 \\
\hline \multirow[t]{3}{*}{ Demand } & 1284800 & 183040 & 183040 & 183040 & 274500 & 274560 & 91520 & 183040 & 1760 & 183040 & \\
\hline & \multicolumn{11}{|c|}{ Average Transportation cost per case (crate) between Potential WH locations } \\
\hline & AA & Bahir Dar & Dessie & Jimma & Nazret & Shashemene & Awash & DD & Gonder & Mekelle & Capacity \\
\hline AA plant & 0 & 33.6 & 24 & 20.1 & 6 & 15 & 14.4 & 30.9 & 44.28 & 46.8 & 2624400 \\
\hline DD plant & 30.9 & 64.5 & 54.9 & 49.8 & 24.9 & 41.7 & 16.5 & 0 & 75.18 & 77.7 & 432000 \\
\hline \multirow[t]{3}{*}{ Demand } & 1284800 & 183040 & 183040 & 183040 & 274560 & 274560 & 91520 & 183040 & 1760 & 183040 & \\
\hline & \multicolumn{11}{|c|}{ Amount to be transported from plant WH } \\
\hline & AA & Bahir Dar & Dessie & Jimma & Nazret & Shashemene & Awash & DD & Gonder & Mekelle & Capacity \\
\hline AA plant & 1284800 & 183040 & 183040 & 183040 & 149840 & 274560 & 0 & 0 & 183040 & 183040 & 2624400 \\
\hline DD plant & 0 & 0 & 0 & 0 & 0 & 0 & 91520 & 183040 & 0 & 0 & 432000 \\
\hline Demand & 1284800 & 183040 & 183040 & 183040 & 274560 & 274560 & 91520 & 183040 & 183040 & 183040 & \\
\hline $\begin{array}{l}\text { Supply } \\
\text { plant }\end{array}$ & $\begin{array}{l}\text { Excess } \\
\text { Capacity }\end{array}$ & & & & & & & & & & \\
\hline AA & 0 & & & & & & & & & & \\
\hline DD & 32720 & & & & & & & & & & \\
\hline \multirow[t]{3}{*}{$\begin{array}{l}\text { Unmet } \\
\text { Demand }\end{array}$} & 0 & 0 & 0 & 0 & 0 & 0 & 0 & 0 & & & \\
\hline & \multicolumn{11}{|c|}{ Amount to be transported from plant WH } \\
\hline & AA & Bahir Dar & Dessie & Jimma & Nazret & Shashemene & Awash & DD & Gonder & Mekelle & $\begin{array}{c}\text { Fixed W } \\
\text { H Cost }\end{array}$ \\
\hline AA & 3 & 33.6 & 24 & 20.1 & 6 & 15 & 14.4 & 30.9 & 44.28 & 46.8 & 0 \\
\hline Bahir Dar & 33.6 & 1.2 & 29.4 & 53.7 & 39.6 & 48.6 & 48 & 64.5 & 10.68 & 52.2 & 200000 \\
\hline Dessie & 24 & 29.4 & 0.9 & 44.1 & 30 & 45 & 38.4 & 54.9 & 40.08 & 22.8 & 150000 \\
\hline Jimma & 20.1 & 53.7 & 44.1 & 0.6 & 26.1 & 53.1 & 34.5 & 51 & 64.38 & 66.9 & 100000 \\
\hline Nazret & 6 & 39.6 & 30 & 26.1 & 1.8 & 11.4 & 8.4 & 24.9 & 50.28 & 52.8 & 170000 \\
\hline $\begin{array}{l}\text { Shashem } \\
\text { ene }\end{array}$ & 15 & 48.6 & 39 & 53.1 & 11.4 & 1.2 & 19.8 & 36.3 & 59.28 & 61.8 & 150000 \\
\hline Awash & 14.4 & 48 & 38.4 & 34.5 & 8.4 & 19.8 & 0.3 & 16.5 & 58.68 & 61.2 & 75000 \\
\hline DD & 30.9 & 64.5 & 54.9 & 51 & 24.9 & 36.3 & 16.5 & 1.5 & 75.18 & 77.7 & 0 \\
\hline Gonder & 44.28 & 10.68 & 40.08 & 64.38 & 50.28 & 59.28 & 58.68 & 75.18 & 0.9 & 62.88 & 120000 \\
\hline Mekelle & 46.8 & 52.2 & 22.8 & 66.9 & 52.8 & 61.8 & 61.2 & 77.7 & 62.88 & 1.2 & 120000 \\
\hline \multirow[t]{3}{*}{ Demand } & 1284800 & 183040 & 183040 & 183040 & 274560 & 274560 & 91520 & 183040 & 1760 & 183040 & \\
\hline & \multicolumn{11}{|c|}{ Amount to be transported from plant WH } \\
\hline & AA & Bahir Dar & Dessie & Jimma & Nazret & Shashemene & Awash & DD & Gonder & Mekelle & Open= 1 \\
\hline AA & 1284800 & 0 & 0 & 0 & 0 & 0 & 0 & 0 & 0 & 0 & 1 \\
\hline Bahir Dar & 0 & 183040 & 0 & 0 & 0 & 0 & 0 & 0 & 0 & 0 & 1 \\
\hline Dessie & 0 & 0 & 183040 & 0 & 0 & 0 & 0 & 0 & 0 & 0 & 1 \\
\hline Jimma & 0 & 0 & 0 & 183040 & 0 & 0 & 0 & 0 & 0 & 0 & 1 \\
\hline Nazret & 0 & 0 & 0 & 0 & 274560 & 0 & 0 & 0 & 0 & 0 & 1 \\
\hline $\begin{array}{l}\text { Shashem } \\
\text { ene }\end{array}$ & 0 & 0 & 0 & 0 & 0 & 274560 & 0 & 0 & 0 & 0 & 1 \\
\hline Awash & 0 & 0 & 0 & 0 & 0 & 0 & 91520 & 0 & 0 & 0 & 1 \\
\hline DD & 0 & 0 & 0 & 0 & 0 & 0 & 0 & 183040 & 0 & 0 & 1 \\
\hline Gonder & 0 & 0 & 0 & 0 & 0 & 0 & 0 & 0 & 183040 & 0 & 1 \\
\hline Mekelle & 0 & 0 & 0 & 0 & 0 & 0 & 0 & 0 & 0 & 183040 & 1 \\
\hline Demand & 1284800 & 183040 & 183040 & 183040 & 274560 & 274560 & 91520 & 183040 & 183040 & 183040 & 1 \\
\hline WH & AA & Bahir Dar & Dessie & Jimma & Nazret & Shashemene & Awash & DD & Gonder & Mekelle & \\
\hline $\begin{array}{l}\text { Excess } \\
\text { Capacity }\end{array}$ & 0 & 0 & 0 & 0 & 0 & 0 & 0 & 0 & 0 & 0 & \\
\hline WH & AA & Bahir Dar & Dessie & Jimma & Nazret & Shashemene & Awash & DD & Gonder & Mekelle & \\
\hline $\begin{array}{l}\text { Unrnet } \\
\text { Demand } \\
\end{array}$ & 0 & 0 & 0 & 0 & 0 & 0 & 0 & 0 & 0 & 0 & \\
\hline & & & & & & 47470227 & & & & & \\
\hline
\end{tabular}


Temesgen Garoma et al.,

In the renewed network optimization, the Dire Dawa Plant which was used to supply only Dire Dawa and its area is now utilized to supply Dire Dawa, Awash and half of Nazareth. In doing so, the company can increase its responsiveness by fully utilizing its whole capacity to supply itself. In this
Sci. Technol. Arts Res. J., April-June 2013, 2(2): 105-114

scenario a total of 366,080 market demands in cases which is equivalent to $8,785,680$ Birr are achieved, and at the same time all demands are met. The final supply chain network design is therefore, as given in figure 2 and 3 respectively.

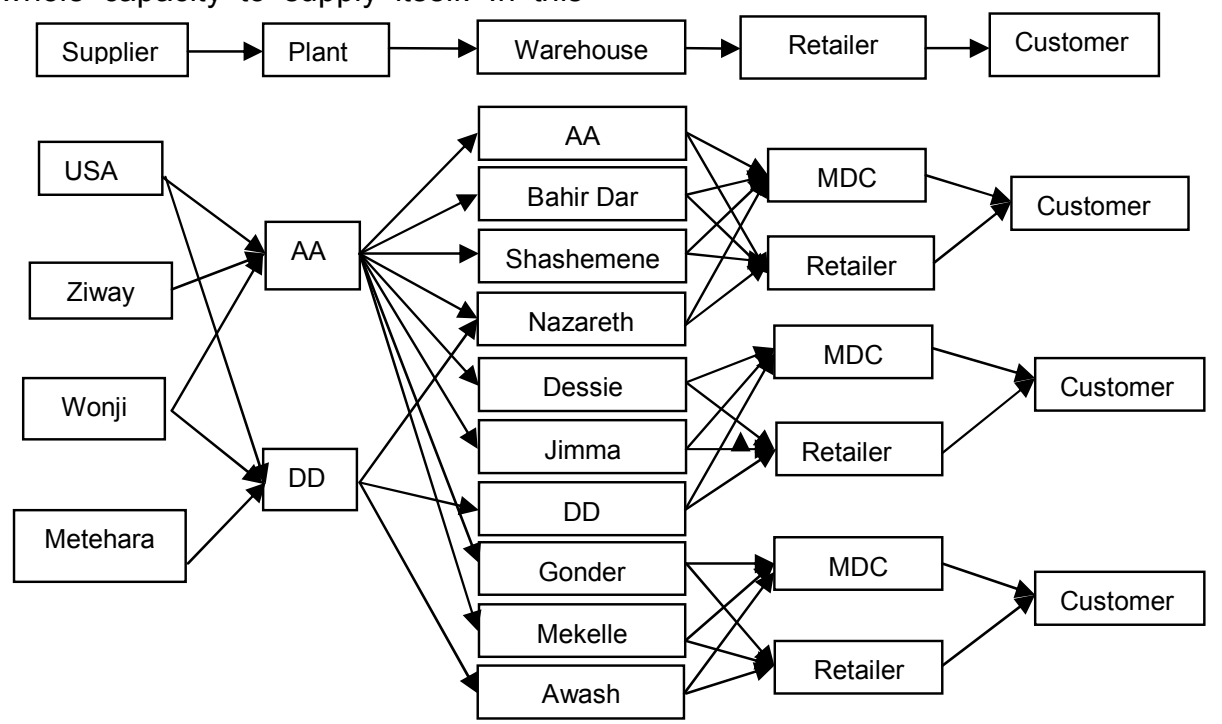

Figure 2: Renewed supply chain network design of the case company.

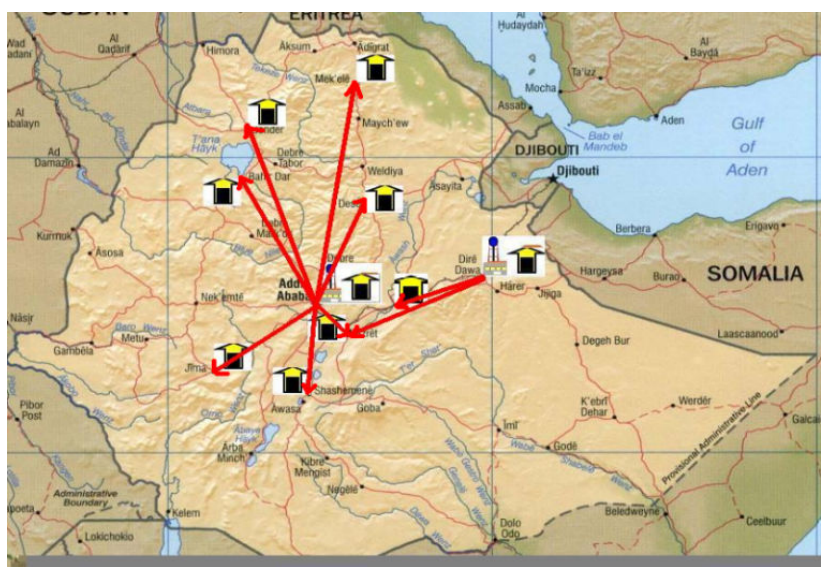

Figure 3: Renewed warehouse locations on the Map of Ethiopia.

\section{CONCLUSIONS}

The objectives of SC network design are to achieve enhanced responsiveness and minimized total distribution cost for manufacturing plant. These objectives are attained through proper modeling of the distribution network and applications of optimization techniques.

In this research, an attempt has been made to model the supply chain network design and justify with the case analysis. The following are the results of the case analysis for East Africa Bottling Share Company:

- Three new warehouses shall be established at Mekelle, Gonder, and Kazanchis.
- Plant at Addis Ababa supplies warehouses at Kazanchis, Bahir Dar, Dessie, Shashemene, Jimma, Gonder, Mekelle, Nazareth, and part of Awash.

- Plant at Dire Dawa ships to Dire Dawa, Awash and some part of Nazareth.

Furthermore, many interesting results are realized. First, by the application of network model optimization techniques, an annual cost saving of 192,192 Birr is achieved. Secondly, by renewing the existing network design of the company a market share of 366,080 cases per year which is equivalent to $8,785,680$ Birr can be realized. 
Temesgen Garoma et al.,

Finally, SC network design has a high economic benefit for manufacturing company. The mathematical model developed and optimization techniques employed here will be good grounds for any similar bottling companies with a need to design appropriate SC network thereby reduce their costs. Therefore, this model could be easily adapted to another manufacturing plant based on their existing operating situations. Furthermore, a future study on multi criteria decision making of warehouse locations for bottling companies is required.

\section{REFERENCES}

Christopher J. (1992). Logistics and Supply Chain Management: Strategies for Reducing Cost, Improving Cost and Improving Services (Boston, MA: Pitman).

Nicholas M. (2005). Competitive Manufacturing Management; Loyal University Chicago: Mc Graw Hill.

Suhong Li., Bhanu Ragu-Nathan., Ragu-Nathan, T.S. and Subba Raol, S. (2006). The Impact of Supply Chain Management Practices on Competitive Advantage and organizational Performance: Omega.

Peter, T. and Groznik, A. (2006). Measurement of Supply Chain Integration Benefits; University of Ljubljanevolume 1.

Change Yoon and Harris Makatsoris (2009); Supply Chain Modeling Using Simulation; Institute for Manufacturing, University of Cambridge, UK: Vol. 2 No. 1.

Gunasekaran A. and Ngai (2004). Virtual supply-chain management, Production Planning \& Control 15(6): 584-595.
Sci. Technol. Arts Res. J., April-June 2013, 2(2): 105-114

Daniel Kitaw and Abrham Debebe (2005). Model Development of Supply Chain Management System- A Case Study on Meta Abo Brewery; ESME Journal, Vol V. No.2, Addis Ababa.

David J. Cross., Eileen McCulloch, and Cheri Speier (1997). The Seven Principles of Supply Chain Management, Reed Business Information, a division of Reed and Elsevier Inc.

Steven A. Melnyk (2006). Supply Chain Management 2010 and Beyond: Mapping the Future of the Strategic Supply Chain; Michigan State University.

Chopra, S. and Meindal P. (2006). Supply Chain Management, Strategy, Planning and Operation, Prentice-Hall, New Delhi, $2^{\text {nd }}$ edition.

Handfield R.B and Nicholas. Emest L. (2006). Introduction to Supply Chain Management, New Deli: PrenticeHall-2006.

Bernard W. Taylor (1996). Introduction to Management Science, fifth edition, Prince Hall , Englewood Cliffs, New Jersey, 1996.

Stamey E. Fawcett., Lisa M. Ellram, and Jeffrey A. Ogden (2007). Supply Chain Management: From Vision to Implementation; Peerson Prentice Hall; India.

Vidal C. (2001). A global supply chain model with transfer pricing and transportation cost allocation. European Journal of Operational Research, 129:134-158.

Beamon M. Benita (1998). Supply Chain Design and Analysis: Models and Methods, International journal of Production Economics 55(3): 281-294.

Thomas E. (2005). Manufacturing Planning and Control for Supply Chain Management, McGraw-Hill, New Delhi, $5^{\text {th }}$ edition, 2005 